\title{
New to doing research and writing papers?
}

\section{Book title:}

Quality research papers,

for students of religion and

theology

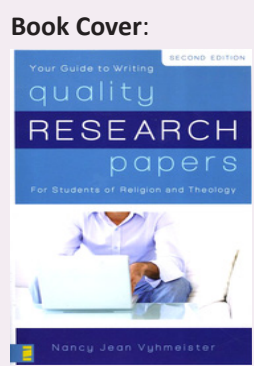

Author:

Nancy J. Vyhmeister

ISSN:

978-0-310-27440-7

Publisher:

Zondervan, 2008, R170.00

*Book price at time of review

\section{Review title:}

New to doing research and writing papers?

\section{Reviewer:}

Raymond Potgieter

\section{Affiliation:}

${ }^{1}$ Faculty of theology, NorthWest University, South Africa

Email:

ray@csmdist.com

Postal address:

PO Box 19491, Noordbrug

2522, South Africa

How to cite this book review: Potgieter, R., 2013, 'New to doing research and writing papers?', In die Skriflig/In Luce Verbi 47(1), Art. \#1766, 2 pages. http://dx.doi. org/10.4102/ids.v47i1.1766

Copyright:

C 2013. The Authors. Licensee: AOSIS

OpenJournals. This work is licensed under the Creative Commons Attribution License.

\section{Read online:}

Are you new to writing a scholarly paper, a dissertation, thesis, book review, or do you find yourself in the midst of doing in-depth research and feel swamped by the glut of information available from so many sources? Do you need a course in research and writing? Then let me recommend a book to any newcomer to scholarly research. Of course, the book deals generically with scholarly research and writing but sufficiently so for any serious students to adapt the author's suggestions to their particular project. For Vyhmeister, research is all about the search and unveiling of God's truth (p. 2), and she gives some insight into how serious a matter this is for her. This statement alone should resonate with anyone in pursuit of truth.

Though primarily written for an American audience, this does not deprecate the book's value. In this updated second edition of the book, you will find a basic step-by-step outline of how to approach your research and write confidently. In this reviewer's opinion, the book has the advantage that it may be used as a tool, and as a rule, it should not be necessary to read it from cover to cover. This is made possible by its extensive table of contents with easy to understand headings which span some 21 chapters. The somewhat arbitrary division of the chapters will lead the reader to the first 13 chapters that explore research, and the rest deal with the actual managing of research to be concluded in writing a paper (dissertation, thesis). Vyhmeister addresses research and the writing of academic papers in such a way that professional writing is presented as a generic blend (cf. chapter 12, p. 113f.). The author provides models illustrating her teaching such as the examples of note cards (pp. 77-8), sample pages of a project (pp. 132-140) and so on, encouraging researchers to use and adapt these models. A slight drawback with this approach is that anyone particularly wanting to refer only to theses and dissertations may be disappointed to find only one chapter (chapter 20, p. 209) covering the subject. However, that would be to miss the point. The book must be viewed as a whole. What the author covers applies to most if not all of academic research and writing.

A cursory, not exhaustive, overview should convince the reader of the book's value. Chapter four (p. 29f.) gives some sound advice on how to settle upon a suitable topic for research. The application of some practical guidelines will finally hone the researcher's general interest down to a particular sphere of interest and with some further guidance settle upon a research project focused on a specific subject, which is usually a struggle for many aspirant postgraduate students. Vyhmeister's useful fence metaphor (p. 33) graphically illustrates this process of delimitation. Some welcome common-sense guidance is found in dealing with bibliographies (p. 45) and footnotes (p. 79), including some insight into developing a research mind set (p. 57). Then there is a step-by-step process for program-development research for pastors up to the stage of final report (p. 163), basic know-how on how to negotiate statistical labyrinths of graphs and tables (p. 189f.) and much more.

Though mainly applicable to the United States, the specific chapter on pursuing professional qualifications, such as Doctor of Ministry and Doctor of Pastoral Theology, may prove to be extremely useful to anyone needing some guidance about how to do practical research. This includes guidance about how to blend the practical with the theoretical into a useful synergy (cf. pp. 221-229).

A little jewel to be found in the book is the little paragraphs introducing transitional words (p. 118). These words connect one sentence to another to continue the development of an idea. Together with the paragraph on how to introduce quotations (p. 119f.), these should prove to be immensely valuable to any researcher putting pen to paper. There are hints on how to keep one's head in the use of tenses, applying correct syntax and more, which is a useful overview for both students and scholars.

A chapter that needs revisiting by the author is chapter three (p. 21f.). This observation is made in light of the increasing importance of the use of the internet not only as a source of data but also 
as a source to verify and corroborate data. Future editions of this book will hopefully keep up with internet and cyberspace developments, particularly as these developments impact upon research and writing, sources and data. Expressly helpful are the explanations and examples given of two reference styles Chicago (Turabian) (chapter 10, pp. 89-102) and APA (American Psychological Association) (Appendix A, pp. 233-243). Although the emphasis is on the former because it is most commonly used in social sciences (inclusive of religion), the latter is usefully expanded (pp. 236-243).

There are many similar books available on writing and research (cf. amazon.com). However, for its sheer comprehensiveness and, albeit brief, attention to thorny matters such as choosing a topic and wrestling with sentence construction, the aspirant researcher would be investing in a tool the pages of which will soon give evidence of use. 